\title{
Experimental Investigation on Behavior of Composite Open Web Steel Joists
}

\author{
Ali Farhan Hadeed \\ Building and Construction \\ Technology Eng. Dep. \\ Al-Esra'a University College, \\ Baghdad, IRAQ \\ engalifarhan@yahoo.com
}

Received: 26-Oct.-2017

\author{
Laith Khalid Al-Hadithy \\ Civil Engineering Dep. \\ Al-Nahrain University, \\ Baghdad, IRAQ \\ lthadithy@yahoo.com
}

\author{
Riyadh J. Aziz \\ Architecture Dep. \\ Al- Esra'a University \\ College, Baghdad, IRAQ \\ riyadhaziz48@yahoo.com
}

http://doi.org/10.29194/NJES.21030393

\begin{abstract}
The composite opened web steel joist supported floor systems have been common for many years. It is economic and has light weight and can embed the electrical conduit, ductwork and piping, eliminating the need for these to pass under the member, consequently eliminate the height between floors. In order to study the joist strength capacity under the various conditions, it had been fabricated seven joists composed of the steel and concrete slab connected to the top chord by shear connectors (headed studs). These joist have $2820 \mathrm{~mm}$ length $\mathrm{c} / \mathrm{c}$ of the supports and 235 mm overall depth. In the present study, six variable parameters are adopted (Studs distribution, Degree of shear connection, Degree of the web inclination, Shape of the web, Density of concrete for slab and length of the shear connector). The test results exhibited that minimum strength capacity was $160 \mathrm{kN}$ for light weight joist and maximum capacity was $225 \mathrm{kN}$ for joist of long shear connectors at failure. The results were compared by ultimate flexural model by Azmi.
\end{abstract}

Keywords: Composite, Open Web, Steel Joists, Analytical Modeling

\section{Notations}

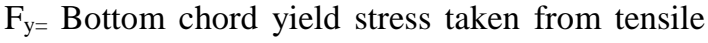
coupon results, $\mathrm{MPa}$

$\mathrm{A}_{\mathrm{s}}=$ Cross sectional area of bottom chord, $\mathrm{mm}^{2}$

$\mathrm{A}_{\mathrm{sc}}=$ Cross -sectional area of stud shear connector, $\mathrm{mm}^{2}$

$\mathrm{b}_{\mathrm{a}}=$ Average rib width, in, Lawson study

$D_{p}=$ Profile height, in, Lawson study

$\mathrm{d}=$ Shear stud diameter, $\mathrm{mm}$, Eurocode equation

$\mathrm{E}_{\mathrm{c}}=$ Elastic modulus of concrete, MPa, AISC equation

$\mathrm{E}_{\mathrm{cm}}=$ Elastic modulus of concrete, $\mathrm{MPa}$, Eurocode equation

$f_{c}^{\prime}=$ Cylinder compressive strength of the concrete, $\mathrm{MPa}$

$\mathrm{f}_{\mathrm{ck}}=$ Characteristic cylinder compressive strength of the concrete, MPa, Euro code equation

$\mathrm{f}_{\mathrm{u}}=$ Ultimate stud strength, Mpa , Euro code equation

$\mathrm{F}_{\mathrm{u}}=$ Ultimate stud strength, MPa, AISC equation
$\mathrm{F}_{\mathrm{y}=}$ Bottom chord yield stress taken from tensile coupon results, $\mathrm{MPa}$

$\mathrm{H}=$ Height of shear connector, in, Lawson study

$\mathrm{h}_{\mathrm{r}}=$ Nominal rib height, $\mathrm{mm}$, AISC equation

$\mathrm{H}_{\mathrm{r}=}$ Length or height of stud, mm, AISC equation

$\mathrm{N}=$ Number of shear connectors per rip, Lawson study

$\mathrm{N}_{\mathrm{r}=}$ Number of stud connectors in one rib, AISC equation

$\mathrm{Q}=$ Shear capacity of single shear stud, $\mathrm{kN}$, Eurocode equation

$\mathrm{Q}_{\mathrm{n}}=$ Nominal stud shear resistance, $\mathrm{kN}$ AISC equation

$r_{p}=$ Stud reduction factor for metal deck, Lawson study

$\mathrm{R} p=$ Stud reduction factor for metal deck, AISC equation

$\mathrm{T}_{\mathrm{y}}=$ Bottom chord yield force taken from tensile coupon results, $\mathrm{KN}$

$\mathrm{V}^{\prime}=$ Total horizontal shear force

$\mathrm{w}_{\mathrm{r}}=$ Average width of concrete rib, mm, AISC equation

Abbreviations

COWSJ=Composite opened web steel joist

CSJs=Composite steel joists

\section{Composite Structure}

In the composite structure, concrete is efficient in compression and steel in tension. Steel components are relatively thin and prone to buckling, concrete can restrain these against buckling, and concrete also gives protection against corrosion and provides thermal insulation at high temperature, finally steel brings ductility into the structure $[1,2]$.

The term composite joist (CJ Series) refers to opened web, parallel chord, load carrying members utilizing hot-rolled or cold-formed steel, including cold-formed steel whose yield strength has been attained by cold working, suitable for the direct support of floors of one-way floor or roof systems ${ }^{4}$. Full connection using shear connectors between the joist top chord and overlying concrete slab allows the steel joist and concrete slab to act together as an integral unit after the concrete has adequately been cured $[3,4]$. Its main advantage is the more efficient and stiffer 
composite design makes it possible to support a given load with a shallower joist [4]. The major limitation according to the Steel Joist Institute (SJI) [4] is, the span of a standard composite joist shall be from 12 to 30 times the depth of the steel joist.

The distinguishing feature of the composite joist system as compared to a non composite system is the presence of shear connectors. The quantity of shear connectors provided is denoted by "shear connectors per half - span" or "shear connectors per shear span", the total number of connectors per member being twice this amount. When used in this study the terms" under connected" and "over connected " will refer to how the shear connection force compares to the yield force of the primary tension resisting component [5].

\section{Experimental Work}

\subsection{Experimental Program}

Degree of connection; either over or under shear connection, based on $\left(\sum \boldsymbol{Q}_{n} / \boldsymbol{T}_{\boldsymbol{y}}\right)$, which is less than one for under connection or more than one for over connection. Individual connector shear strength $\left(\boldsymbol{Q}_{\boldsymbol{n}}\right)$ must be computed according to the steel manual AISC20056. The number of shear connectors at balance state can be estimated by dividing the total horizontal shear force $\left(V^{\prime}\right)$ by $\left(Q_{n}\right)$.The total horizontal shear force $\left(V^{\prime}\right)$ is the lowest value of the limit states of concrete crushing $\left(\mathbf{0 . 8 5 f ^ { \prime }} \boldsymbol{A}_{\boldsymbol{c}}\right)$ and tensile yielding of the bottom chord ( $\left.\mathbf{A}_{\mathbf{s}} \mathbf{F}_{\mathbf{y}}=\mathbf{T}_{\mathbf{y}}\right)$ according to steel manual,AISC,2005 [6]. ( $\left.\boldsymbol{T}_{\boldsymbol{y}}\right)$ is the bottom chord yield force taken from laboratory test result. In this study 6.2 studs need for balancing, so ten studs were used for over connection $(62 \%)$ and five for under connection (19\%). Six main variables were adopted and seven steel joists were constructed to investigate the effects of each variable. The first joist was considered as the reference one, with slab of normal weight concrete(NWC), its strength $27 \mathrm{MPa}$, steel angle web with $45^{\circ}$ inclination, over shear connection with short height $(30 \mathrm{~mm})$, headed studs uniformly distributed The second had nonuniform stud distribution. Under Shear connection was implemented in the third joist, while $34^{\circ}$ inclination of web angle was the variable of the fourth one. The fifth was distinguished by variable $\emptyset 25 \mathrm{~mm}$ rounded bar web member. The variable of Light weight slab concrete (LWC) of $26.5 \mathrm{MPa}$ was used in manufacturing the sixth composite joist. The seventh had long headed stud $(50 \mathrm{~mm})$.all previous details are given in table 1.

Table1 Details of tested joists with their parameters

\begin{tabular}{|c|c|c|c|c|c|c|c|}
\hline \multirow[t]{2}{*}{$\begin{array}{c}\text { Joist } \\
\text { Designation }\end{array}$} & \multirow[t]{2}{*}{$\begin{array}{c}\text { Slab } \\
\text { conc. } \\
\text { Type } \\
\end{array}$} & \multicolumn{2}{|c|}{ Web details } & \multicolumn{4}{|c|}{$\begin{array}{l}\text { Shear connector } \\
\text { ( headed stud) }\end{array}$} \\
\hline & & Shape & Inclination & Length & $\begin{array}{c}\text { Mode of } \\
\text { distribution }\end{array}$ & Degree of connection & $\begin{array}{l}\text { Studs No. } \\
\text { Per half } \\
\text { span }\end{array}$ \\
\hline CSJ-1(B1) & NWC & Double Angle & $45^{\circ}$ & (short) & Uniformly & Over connection & 10 \\
\hline CSJ-2(B2) & NWC & Double Angle & $45^{\circ}$ & (short) & Non-Uniformly $^{*}$ & Over connection & 10 \\
\hline CSJ-3(B3) & NWC & Double Angle & $45^{\circ}$ & (short) & Uniformly & Under Connection $^{*}$ & 5 \\
\hline CSJ-4(B4) & NWC & Double Angle & $34^{\circ *}$ & (short) & Uniformly & Over connection & 10 \\
\hline CSJ-5(B5) & NWC & Rounded Bar ${ }^{*}$ & $44^{\circ}$ & (short) & Uniformly & Over connection & 10 \\
\hline CSJ-6(B6) & LWC* & Double Angle & $45^{\circ}$ & (short) & Uniformly & Over connection & 10 \\
\hline CSJ-7(B7) & $\overline{\mathrm{NWC}}$ & Double Angle & $45^{\circ}$ & (long) $^{*}$ & Uniformly & Over connection & 10 \\
\hline
\end{tabular}

\subsection{Push out Test}

Three push out test specimens including 4 studs, $\Phi 10 \mathrm{~mm}$ for each were fabricated according to the BS5400-part 5 [7]. Each of them was set up under the hydraulic jack of the $3000 \mathrm{kN}$ capacity MFL machine. A dial gauge of $0.01 \mathrm{~mm}$ accuracy was fixed at web of steel I - section beam with level of headed stud immersed in the concrete slab. Plate 1 depicted the actual setup of the specimen while Fig. 1 represented the standard of push out test.

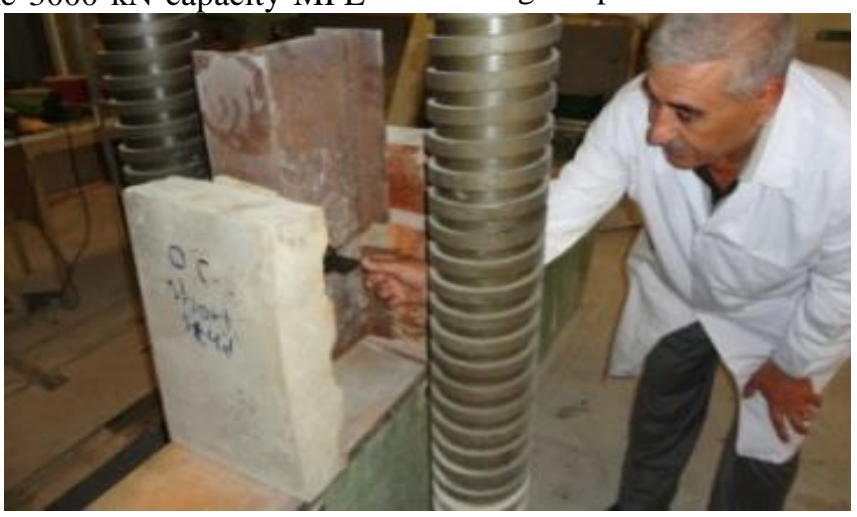

Plate 1 Setup for the push-out test 

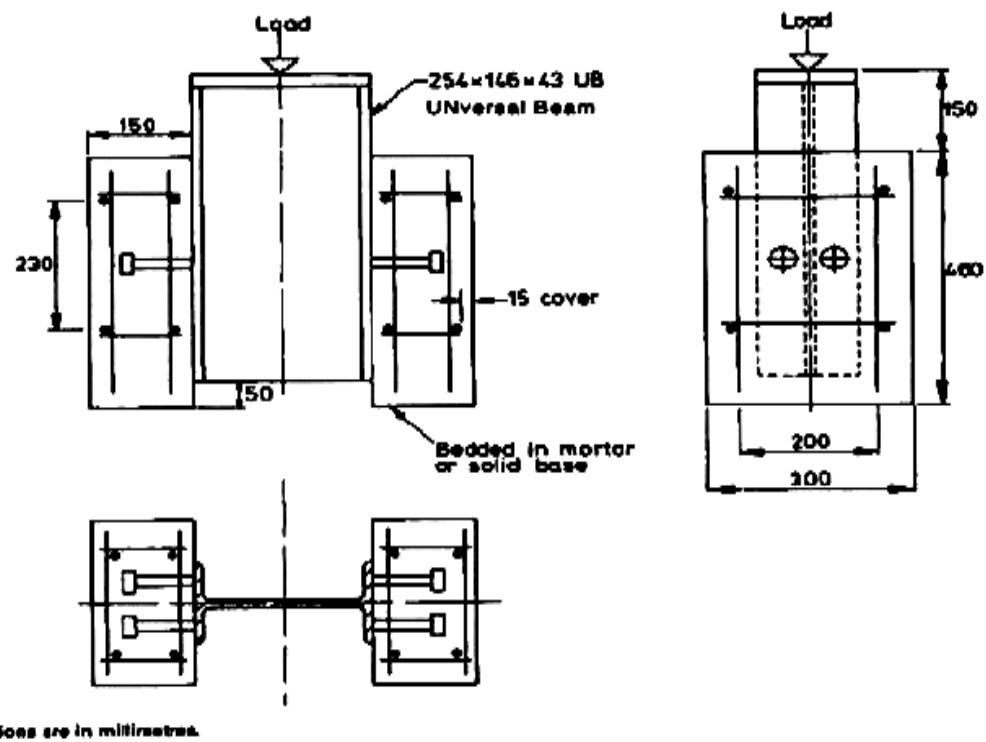

Figure 1: Standard of push- out test

\subsection{Joists Construction and Instrumentations}

Typically, each of the seven test specimens consisted of single simply supported composite joist effectually joined by ten mechanical shear connectors to $60 \mathrm{~mm}$-thick cast-in- place concrete slab through the corrugated steel deck of gauge 20 $(0.9 \mathrm{~mm}$ thick). Each joist had been constructed with clear span of $2820 \mathrm{~mm}$ and depth of $235 \mathrm{~mm}$ to obtain the span- depth ratio equal to (12).The overall span length was $3000 \mathrm{~mm}$ with limited width of the concrete slab of $400 \mathrm{~mm}$ to simplify laying the joist between the screw shafts of the testing flexural machine,. The joist members were arranged in a warren truss configuration. Steel double angles were used to construct top and bottom chords have the same cross sectional. Double angles, also used for the web members, except the web of joist 5 were constructed using rounded steel bar with $25 \mathrm{~mm}$ diameter. Figs 2, 3 and plate 2 showed above details. Headed studs of $10 \mathrm{~mm}$ diameter as a shear connectors were used. $30 \mathrm{~mm}$ stud height for all joist, except joist 7 has $50 \mathrm{~mm}$ stud height. Fig. 4 shows the stud distribution.

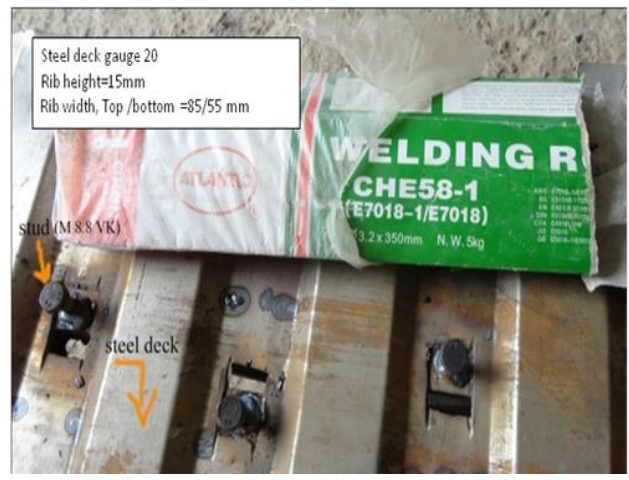

Plate 2: Corrugated sheets and shear connectors

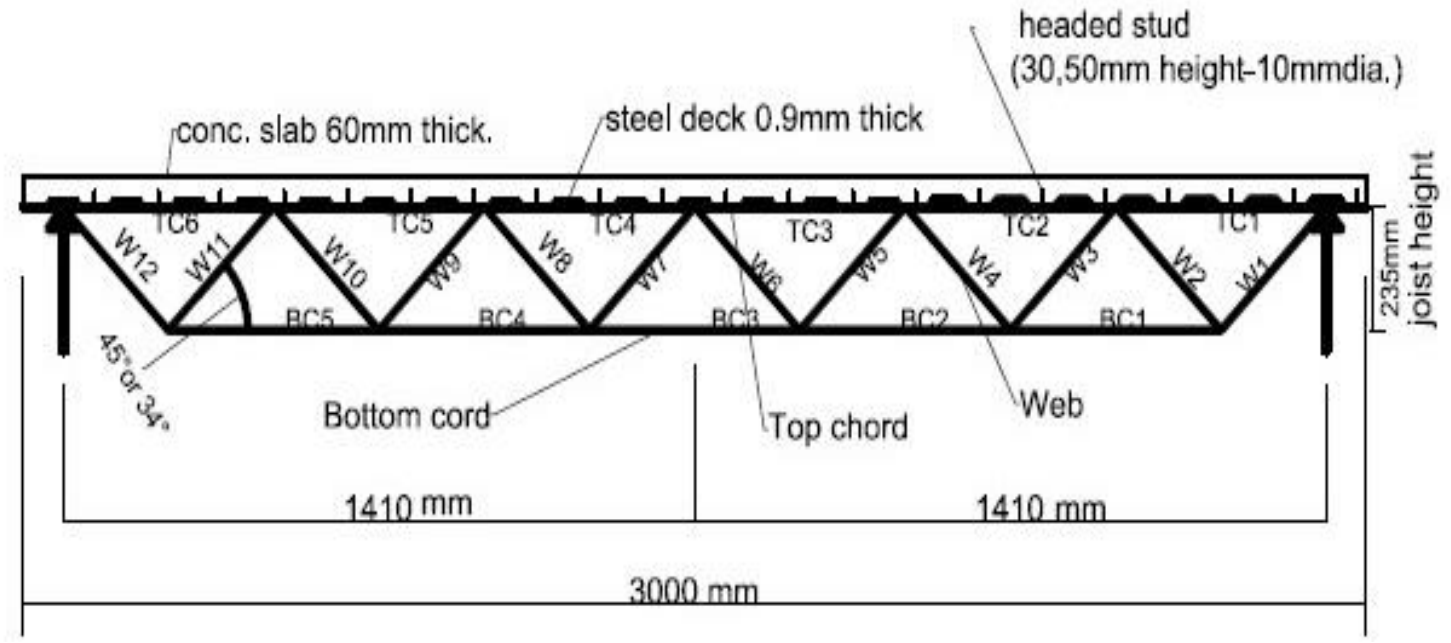

Figure 2: Joist configuration details 


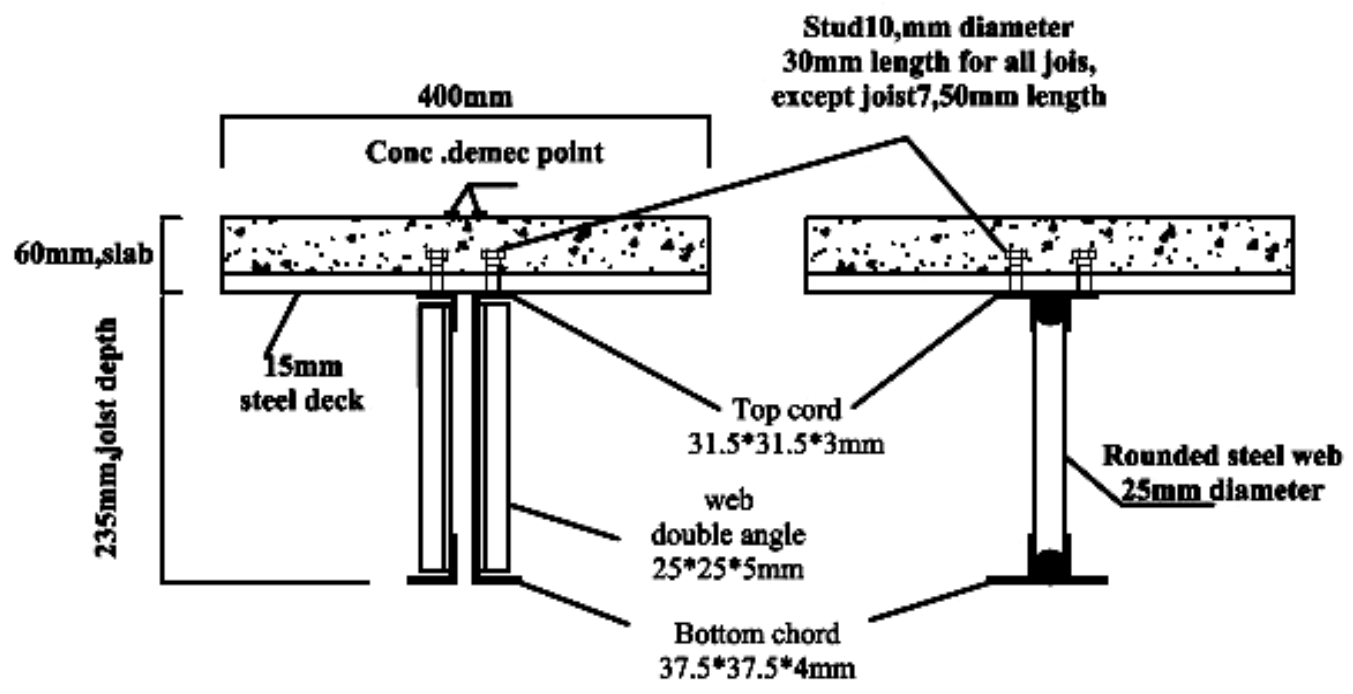

a-Cross section for josts $1,2,3,4,6,7$

b-Cross section for joist5

Figure 3: Cross sections for Joists

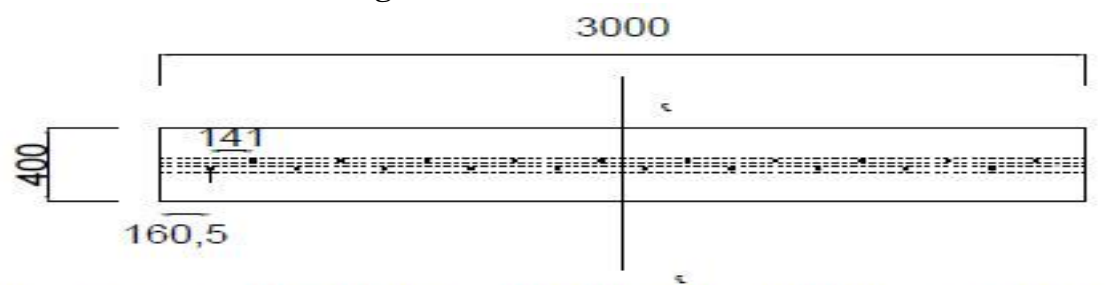

Over Connection Uniform Distribution Studs -Joists 1,4,5,6,7

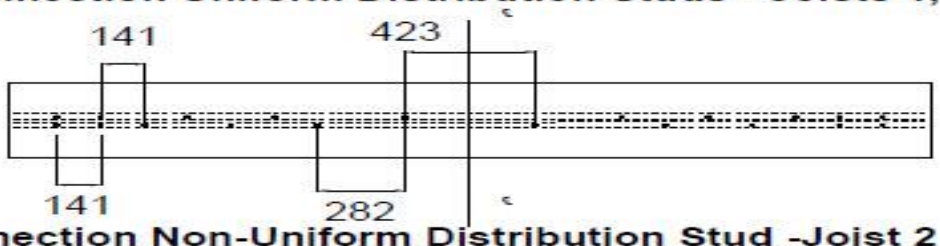

Over Connection Non-Uniform Distribution Stud-Joist 2

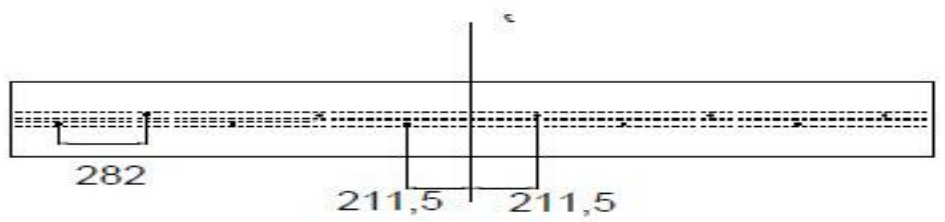

Under Connection Uniform Distribution Studs-Joist 3

Note :All dimensions in $\mathrm{mm}$

Figure 4: Distribution of shear connectors (Studs)

Similar instrumentation patterns were used for each joist test. A mechanical method was used for strain measurement at the mid span top slab; one row of demec point was fixed at the top face of slab shown in Fig.3, in order to record slab strains .Its reading scale accuracy was $0.002 \mathrm{~mm}$. Top and bottom cords were labeled (TC1toTC6) and (BC1 to BC5) respectively. The symbols (R) and (L) represented right and left leg of cord. For webs the symbols were (W1toW11). Joist 4 instrumentations have little difference. Metal Strain gauges were installed with labeling (G1to G8and glued by adhesive P-2). (R) and (L) indicated the gauge installed at right or left cord leg respectively. Two LVDTs (Linear variable differential transformers) instruments of $100 \mathrm{~mm}$ capacity were located at the two ends of each joist to read the relative movements (slips) at the interfaces between the top cord and the slab. LVDTF9 and LVDTB10 indicated to the front and back locations, respectively. Mid-span and quarter-span deflections were measured using dial gauges of $0.01 \mathrm{~mm}$ accuracy. Electrical data logger denoted TDS 530 of ten reading channels was used to control the strains of the cords and the end relative slips for each joist. Fig. 5 and plate 3 and 4 gave the instrumentations details. 


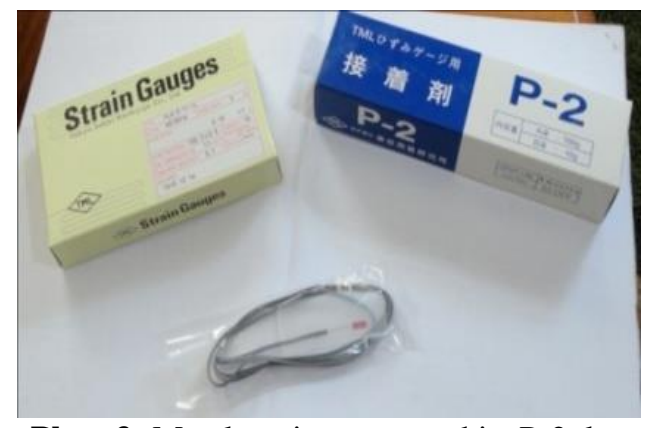

Plate 3: Metal strain gauge and its P-2glue

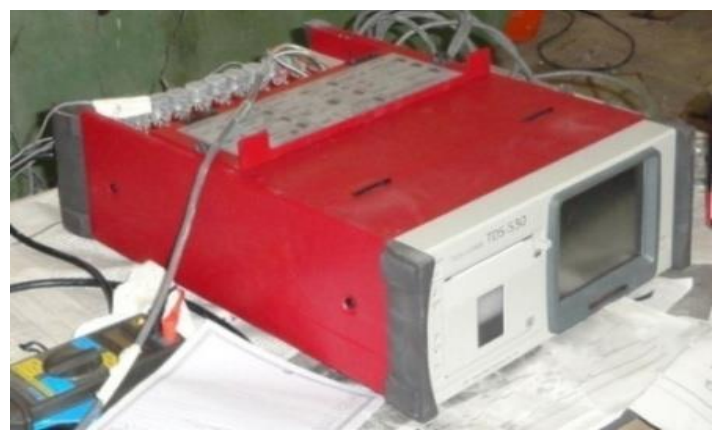

Plate 4: Data Logger TDS 530

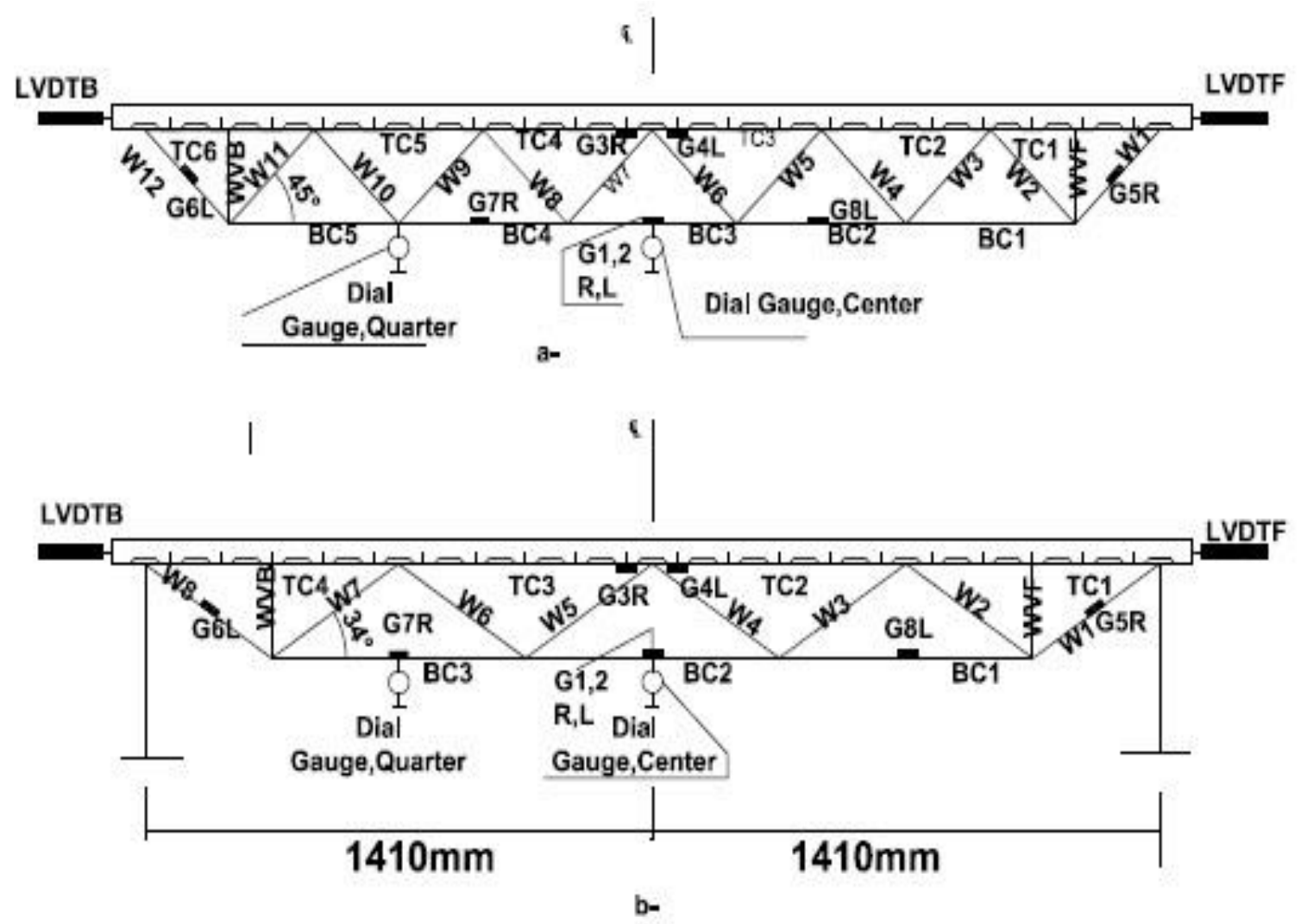

Figure 5: Members designation and strain gauges locations a- joists $(1,2,3,5,6,7)$, b- joist4

\subsection{Joist Loading Procedure}

A flexural machine with $3000 \mathrm{kN}$ hydraulic jack was used to apply equal load to two points over a series of spreader beams (which their weights taken in dead load computations), used to distribute the applied load to the specimens by eight load points as shown in Fig. 6 and Plate 5.

\section{Results and Discussion}

\subsection{Push- out Test Results}

The experimental results of push-out test are compared with the (AISC-2005) ${ }^{6}$ and euro-code $(1994)^{8}$ equations, these results revealed acceptable values. Long headed stud exhibited more strength than others due to the ductility gained by increasing in its projection embedded in slab above the top of the steel deck. The results are given in table 2 .

Euro code Equation (1994) [8] $q=0.8 * f_{u} *\left(J d^{2} / 4\right) \leq q=0.29 d^{2} \sqrt{ }\left(f_{c k} E_{c m}\right) . .1$ Where, the applicable stud shear reduction factor for steel deck from Lawson study

(1993) [9] is:

$$
r_{p}=0.75 / \sqrt{ } N^{*} b_{a} / D_{p *}\left[h /\left(h+D_{p}\right)\right] \leq 1.0 \ldots \ldots .2
$$

AISC Equation (2005)

$$
\mathbf{Q}_{\mathbf{n}}=\mathbf{0 . 5} \mathbf{A}_{\mathbf{s c}} \sqrt{ }\left(\mathbf{E}_{\mathbf{c}} \boldsymbol{f}_{\mathbf{c}}^{\prime}\right) \leq \mathbf{A}_{\mathbf{s c}} \mathbf{F}_{\mathbf{u}} \ldots \ldots \ldots . .3
$$

The strength reduction factor for metal deck oriented perpendicular to the joist span from the LRFD specification is:

$\boldsymbol{R F}=\mathbf{0 . 8 5} / \sqrt{ }_{N_{r}} * w_{r} / h_{r}\left[\left(H_{r} / h_{r}\right)-1\right] \leq 1.0 \ldots \ldots .4$

If $\boldsymbol{R} \boldsymbol{F}$ more than 1.0 the ratio of actual flange thickness to the recommended minimum flange thickness must be checked, which is considered as a reduction factor for thin steel flange, so Minimum $t_{f}=0.4($ stud dia.) Goble(1968) [10]. In this study, $3 \mathrm{~mm}$ thick top chord angles and 10 $\mathrm{mm}$ diameter studs result in the provided flange thickness (in terms of stud diameter). Actual $\boldsymbol{t}_{f}$ 
NJES Vol.21, No.3, 2018

$=0.3($ stud dia $)$. Reduction factor for thin base

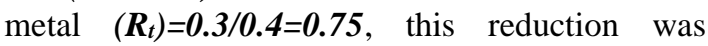
considered for the calculation of the stud shear capacity.

Hadeed et al., pp.393-404

3.2 Ultimate load carrying capacity for joists

The experimental load capacities of the joists ranged from (160 -225) $\mathrm{kN}$ as shown in table 3.The joist of long studs bears maximum load was about $225 \mathrm{kN}$.
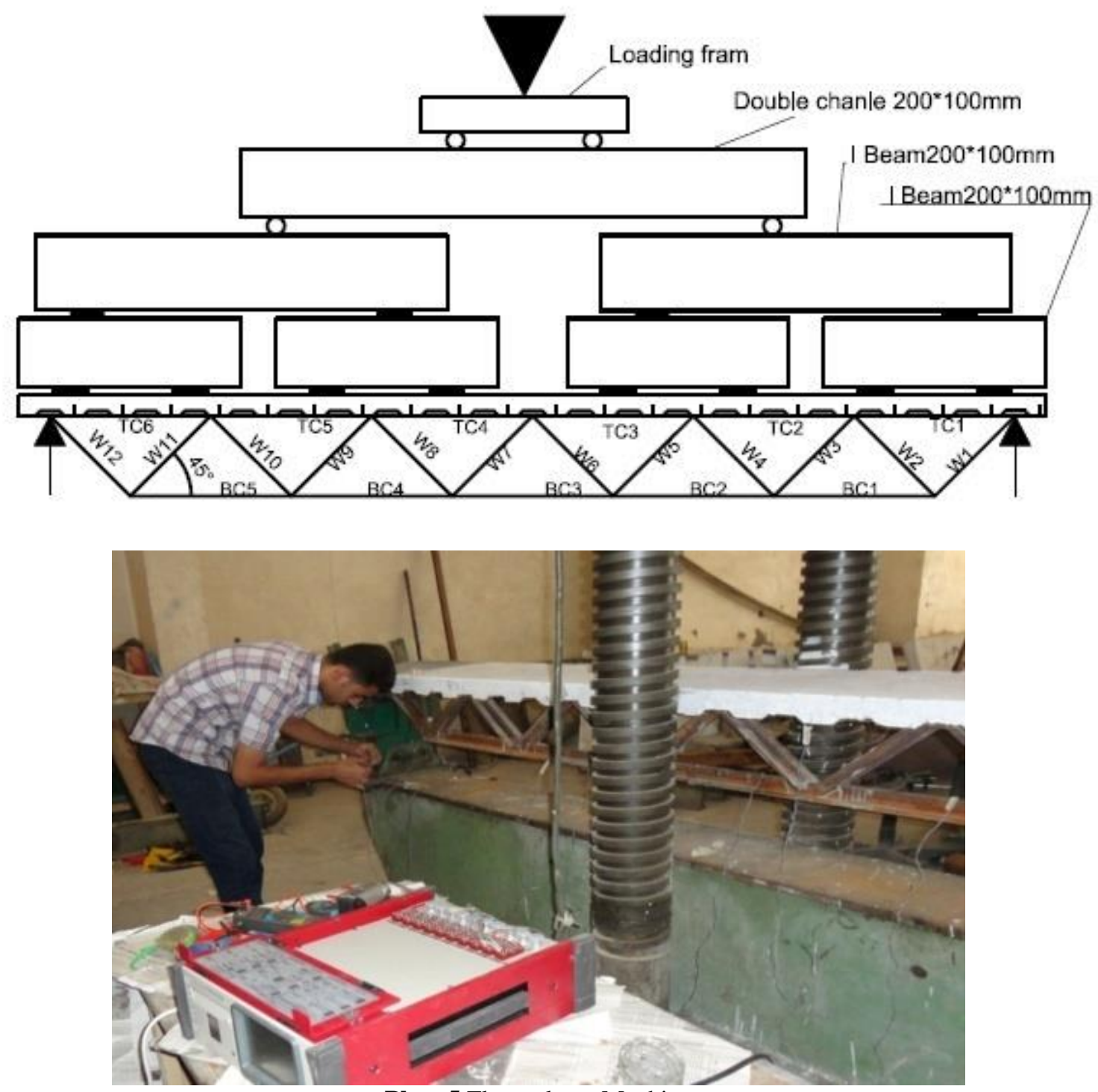

Plate 5 Flexural test Machine

Table 2 Push out test results

\begin{tabular}{|c|c|c|c|c|c|c|c|c|}
\hline Speci-men & $\begin{array}{l}\text { Ulti- } \\
\text { mae } \\
\text { load } \\
(\mathbf{k N})\end{array}$ & $\begin{array}{l}\text { Ulti- } \\
\text { mae } \\
\text { slip } \\
(\mathbf{m m})\end{array}$ & $\begin{array}{l}\text { Shearing } \\
\text { Resist-ance } \\
\text { per stud } \\
(\mathbf{k N})\end{array}$ & $\begin{array}{c}\text { Slip at } 50 \% \\
\text { of stud } \\
\text { shear force } \\
(\mathrm{mm})\end{array}$ & $\begin{array}{c}\text { Shearing } \\
\text { Rigidity } \\
\text { (Ks) } \\
(\mathbf{k N} / \mathbf{m m})\end{array}$ & $\begin{array}{c}\text { Shearing } \\
\text { Rigidity } \\
\text { (Ks) } \\
\text { (kN/mm) } \\
\text { Euro-Code } \\
\text { Equation }\end{array}$ & $\begin{array}{c}\text { Sheari-ng } \\
\text { Rigidity } \\
\text { (Ks) } \\
\text { (kN/mm) } \\
\text { AISC } \\
\text { Equation }\end{array}$ & $\begin{array}{c}\text { Mode of } \\
\text { Failure }\end{array}$ \\
\hline $\begin{array}{l}\text { Slab NWC, } \\
\text { Short Stud } \\
\end{array}$ & 120 & 1.48 & 30 & 0.21 & 71.43 & 23.83 & 24.4 & $\begin{array}{l}\text { Concrete } \\
\text { Crushing }\end{array}$ \\
\hline $\begin{array}{c}\text { Slab NWC, } \\
\text { Long Stud } \\
\end{array}$ & 140 & 2.54 & 35 & 0.94 & 19 & 23.83 & 24.4 & $\begin{array}{l}\text { Concrete } \\
\text { Crushing }\end{array}$ \\
\hline $\begin{array}{l}\text { SlabL WC, } \\
\text { Short Stud }\end{array}$ & 106 & 0.71 & 26.5 & 0.26 & 51 & $\begin{array}{c}0.85 * 23.83 \\
=20.26\end{array}$ & $\begin{array}{c}0.85 * 24.4 \\
=20.74\end{array}$ & $\begin{array}{l}\text { Concrete } \\
\text { Crushing }\end{array}$ \\
\hline
\end{tabular}


Table 3: Ultimate load capacity

\begin{tabular}{|c|c|c|}
\hline $\begin{array}{c}\text { Test } \\
\text { Designation }\end{array}$ & Characteristic & $\begin{array}{c}\text { Load per Joist at } \\
\text { failure (kN) }\end{array}$ \\
\hline CSJ-1(B1) & Reference , uniform stud distribution & 210 \\
\hline CSJ-2(B2) & Non uniform stud distribution & 198 \\
\hline CSJ-3(B3) & Under connection-shear stud & 190 \\
\hline CSJ-4(B4) & Web inclination - 34 & 190 \\
\hline CSJ-5(B5) & Rounded web shape & 189 \\
\hline CSJ-6(B6) & LWC slab & 160 \\
\hline CSJ-7(B7) & Long shear stud & 225 \\
\hline
\end{tabular}

\subsection{CSJs Experimental Response}

The linear behavior shown in the curves that will be discussed below indicates the full composite action for joists whereas the non-linear behavior indicates the non composite action due to the deterioration of shear connection between the slab and the studs.

\subsubsection{CSJ-1 Experimental Response}

This joist was considered as a reference for general structural behavior for other joists. At applied load of $151.35 \mathrm{kN}$ the bottom chord yielded at load stage of $185.62 \mathrm{kN}$. The system deflection and strains of top and bottom chords behaved linearly elastically up to a load approximately $150 \mathrm{kN}$ in addition for slab strain as in Figs $(7,8,9$, and 12). The cords were under tension action. Failure occurred at a load of $210 \mathrm{kN}$.W1and W11 suffered from tension and compression strains respectively during the test as in Fig 10. At $150 \mathrm{kN}$ load level there was noticeable slips. The presence of slip indicates no full interaction between the slab and the steel top chord, as in Fig. 11. It was found the $1^{\text {st }}$ and $2^{\text {nd }}$ headed stud's shank exhibited distorted shape due to the horizontal shear flow, as in Plate 6. Full separation between the steel deck and slab was observed uniformly along the span within the loading of $210 \mathrm{kN}$, indicating full shear connection deterioration. The uniform stud's distribution had enabled to control the uniform separation along span, as in Plate 7.

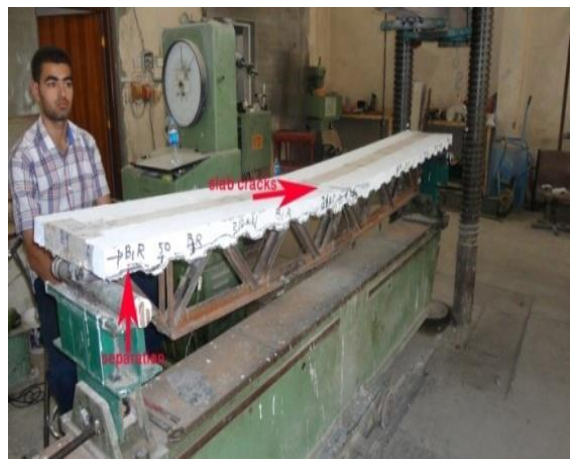

Plate 6 Fracture pattern of CSJ-1

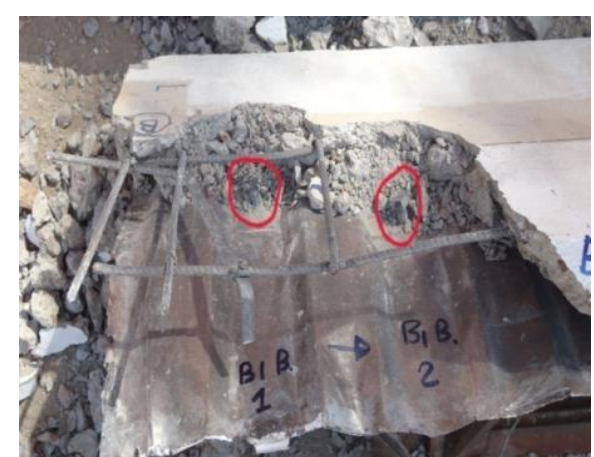

Plate 7 Distorted headed stud of CSJ-1

\subsubsection{CSJ-2 Experimental Response}

Bottom chord reached yield limit of $185.62 \mathrm{kN}$ when applied load was $137.7 \mathrm{kN}$. The system deflection and strains of top and bottom chords behaved linearly elastically up to a load approximately $100 \mathrm{kN}$ also for slab strain as in Figs. (7, 8, 9, and 12). The cords were under tension action in this stage. Full failure occurred at $198 \mathrm{kN}$.The strains in the chosen webs $(W l$, W11) indicated tension and compression response respectively as designed and shown in Fig.10. An existing end slips until $100 \mathrm{kN}$ load level at both joist ends due to the shear studs amounts near the supports as in Fig.11. Deck separation began near the supports at the $150 \mathrm{kN}$ and directly ahead at mid span in the range of $170-195 \mathrm{kN}$ loading stage. The non uniform distribution of studs along the span caused non uniform deck separation. Plates 8 and 9 shows the deck separation and stud distortion receptively. This joist exhibited well ductile manner as in fig.7.

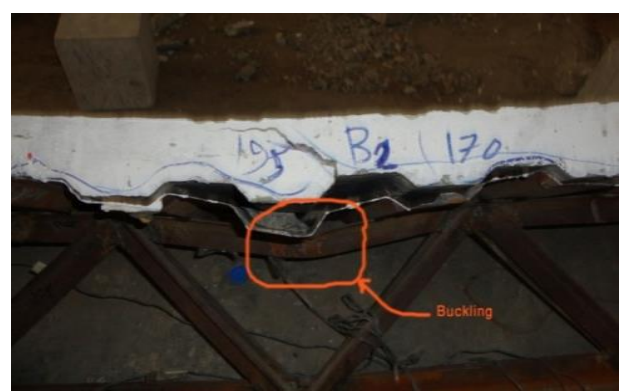

Plate 8 Steel deck separation pattern and top cord buckling shape in CSJ-2 
NJES Vol.21, No.3, 2018

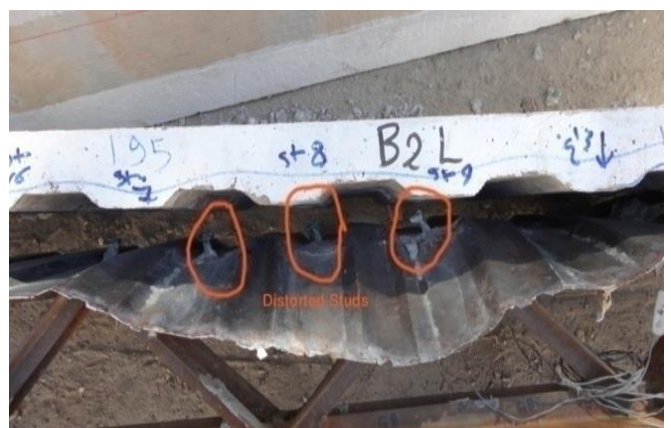

Plate 9: Distorted headed stud of CSJ-2 at failure

\subsubsection{CSJ-3 Experimental Response}

Yielding strength of $185.62 \mathrm{kN}$ occurred at applying load of $134.6 \mathrm{kN}$. Bottom chord reached yield limit of $185.62 \mathrm{kN}$ when applied load was $137.7 \mathrm{kN}$. The system deflection and strains of top and bottom chords behaved linearly elastically up to a load approximately $160 \mathrm{kN}$ but for slab strain was about $80 \mathrm{kN}$ as in Figs. (7, 8, 9, and 12 ). The cords were under tension action in this stage. Beyond that, the specimen acted none linearly due to non- composite action, caused by the separation of the shear connection studs beginning after the load stage of $120 \mathrm{kN}$ as shown in plates 10 and 11.Failure load was $190 \mathrm{kN}$.The webs Wland W11, undergoing tension and compression strains, respectively as in Fig 10.There is tension relative slips at the joist ends because of the low interaction between the contacted faces, due to less amount of shear studs (under connection) as in Fig.11. The under connection, uniform distribution of stud along the joist span exhibited well stiff behavior that relieved in load-deflection curve given in Fig.7

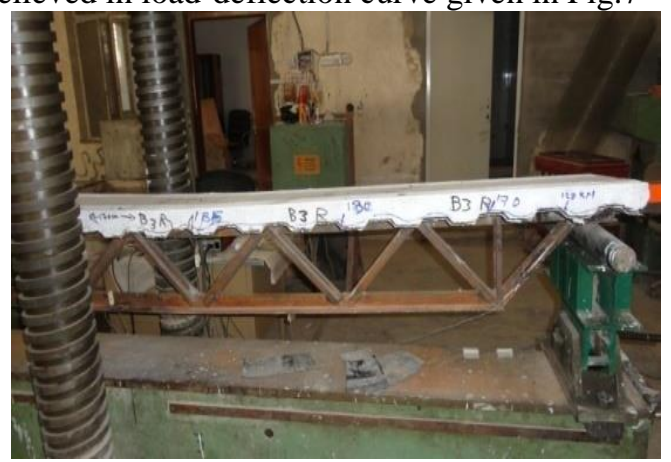

Plate 10: Fracture pattern of CSJ-3

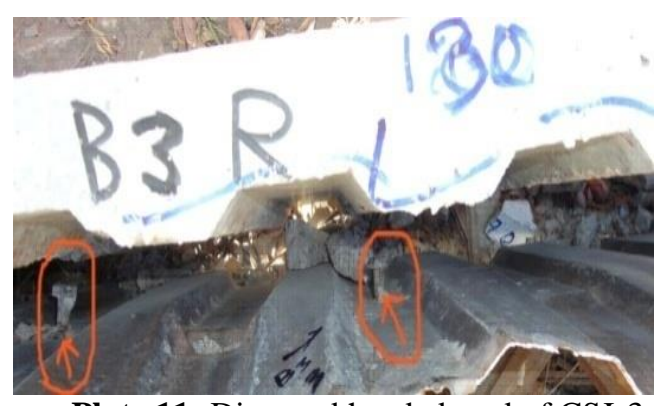

Plate 11: Distorted headed stud of CSJ-3

\section{Hadeed et al., pp.393-404}

\section{3-.3.4 CSJ-4 Experimental Response}

Bottom chord was yielded when applied load had reached $121 \mathrm{kN}$. Deflection has approximately linear behavior up to $120 \mathrm{kN}$, also for top and bottom chord as in Figs (7, 8, and 9), but concrete in slab crushed at $80 \mathrm{kN}$ load (strain $=0,003$ ) as in Fig.12. Failure took place at $190 \mathrm{kN}$ loading stage. W1 suffered from tensile strain, while W11 in compressive strain as in Fig.10. Relative slip at ends of the joist between was existing, pointing no full interaction. Steel deck separation started at $90 \mathrm{kN}$ loading stage and propagated towards mid span through the load increments as shown in Plate 12. Plate 13 shows the stud's distortion.

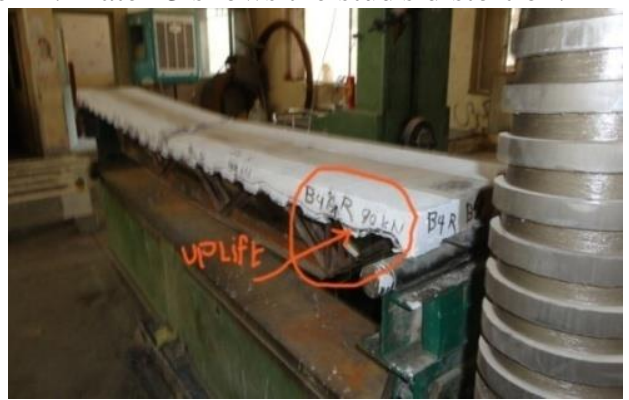

Plate 12: CSJ-4 after loading up to failure

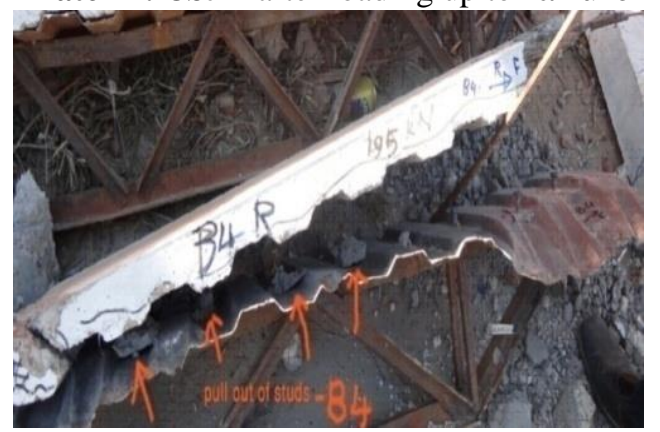

Plate 13: Studs distortion of CSJ-4

\subsubsection{CSJ-5 Experimental Response}

Bottom chord yielded at $147.5 \mathrm{kN}$ applied load level. For deflection behavior, an approximately linear trend up to a load level of $120 \mathrm{kN}$ the same behavior for the top and bottom chords as in figs.7, 8 and 9. Right side of bottom chord exhibited more strain than left side at failure stage, due to lateral movement, because of single rounded web configuration, so the horizontal bridging must be taken in the consideration during the construction. Fig. 10 shows no yielding happened in the web members coinciding with their over deigned. Small relative horizontal slips exist until $40 \mathrm{kN}$ as in Fig. 11. Strains in slab behaved in compression linearly till a loading level of $120 \mathrm{kN}$, shown Fig.12. The separation of steel deck was clearly seen when the loading level reached $187 \mathrm{kN}$ indicating non- composite action as shown in Plate 14. Plate 15 shows five distorted studs. The system failed at $189 \mathrm{kN}$ load stage. 
NJES Vol.21, No.3, 2018

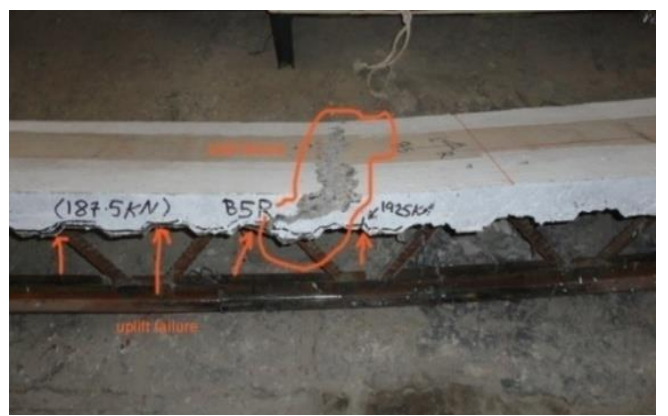

Plate 14: Steel deck separation pattern for CSJ-5

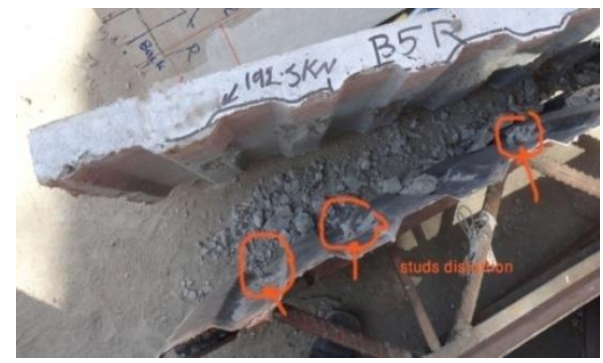

Plate 15 Studs distortion at failurefor CSJ-5

\subsubsection{CSJ-6 Experimental Response}

At the $130.03 \mathrm{kN}$ load level the bottom chord yielded by $185.62 \mathrm{kN}$ force.This joist revealed linear behavior until $130 \mathrm{kN}$ load level according the deflection curve presented in Fig.7.Figs 8and 9 show the same behavior in the top and bottom chords. As designed, the W1 and W11 resisted tensile and compression strains respectively as in Fig 10. Relative slips occurring showed partial connection in the composite system that is shown in Fig 11. Slab deformation was linear compression behavior continued till $50 \mathrm{kN}$ loading stage that shown in Fig. 12, the slab withstood compressive action to the crushing load level of $160 \mathrm{kN}$.That was due to the exits of deck ribs which acted as reinforcement at the bottom fiber of the slab, besides the exits of studs, restrained the concrete in between. The deck separation was at 9okN load level while the studs not distorted and their strength may be more than that of light concrete. The joist failed at $160 \mathrm{kN}$ load level.plate 16 shows the joist after failure, while plate 17 depicted no distortion in studs.

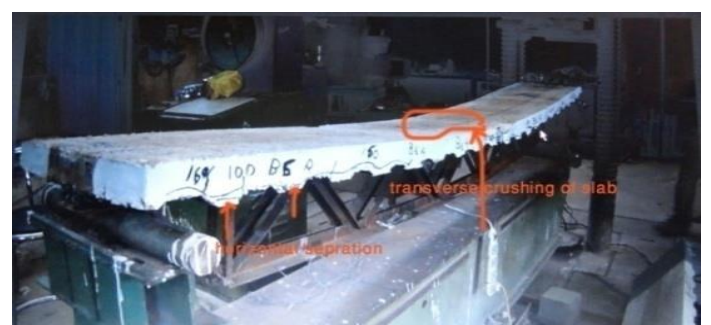

Plate 16: Deck separations, slab crushing, CSJ-6
Hadeed et al., pp.393-404

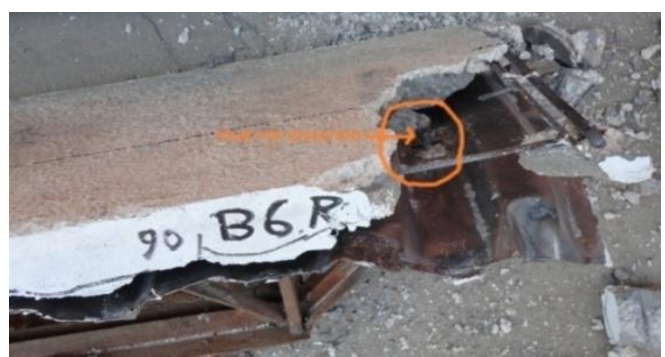

Plate 17: Never distorted headed stud, CSJ-6

\subsubsection{CSJ-7 Experimental Response}

Bottom chord yielded with strength of 185.62 $\mathrm{kN}$ when applied load reached $133.5 \mathrm{kN}$. Linear deflection behavior reached the $150 \mathrm{kN}$ load level, that was the same for top and bottom chords indicating composite action as shown in Figs.( 7 , 8 and 9). WI and W11 exhibited tensile and compression strains, as expected as in Fig.10. Figure 11 shows the slip progressing indicating no full interaction at the interface region. Strains at top face of the slab varied linearly until the $70 \mathrm{kN}$ load level as in Fig.12. Due to long studs, the uplift and separation did not occur up to $220 \mathrm{kN}$ loading stage as in plate.18. Plate 18 shows the joist at failure. There was no significant headed stud's distortion, however, the first and second headed stud near the support suffered from the small distortion and little curvature at its mid height due to high horizontal axial block concrete stress as shown in Plate 18. Failure load was $225 \mathrm{kN}$.

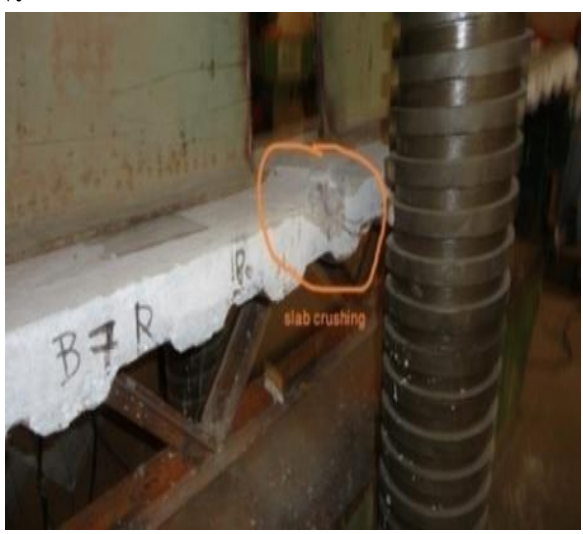

Plate 18: CSJ-7specimen after failure

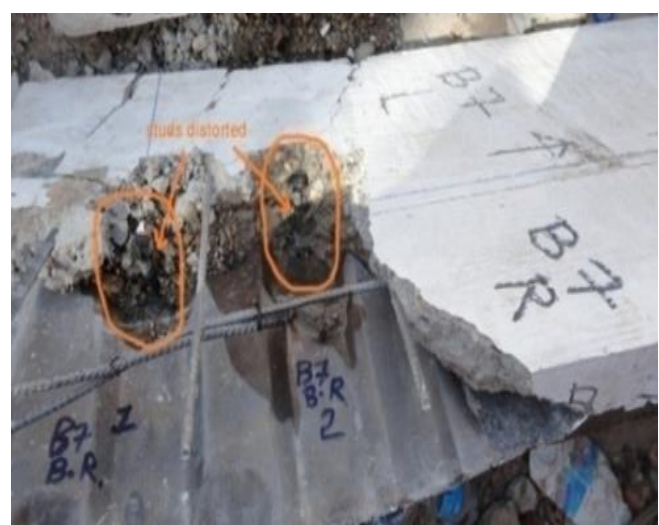

Plate 19: Studs distortion in CSJ-7specimen 


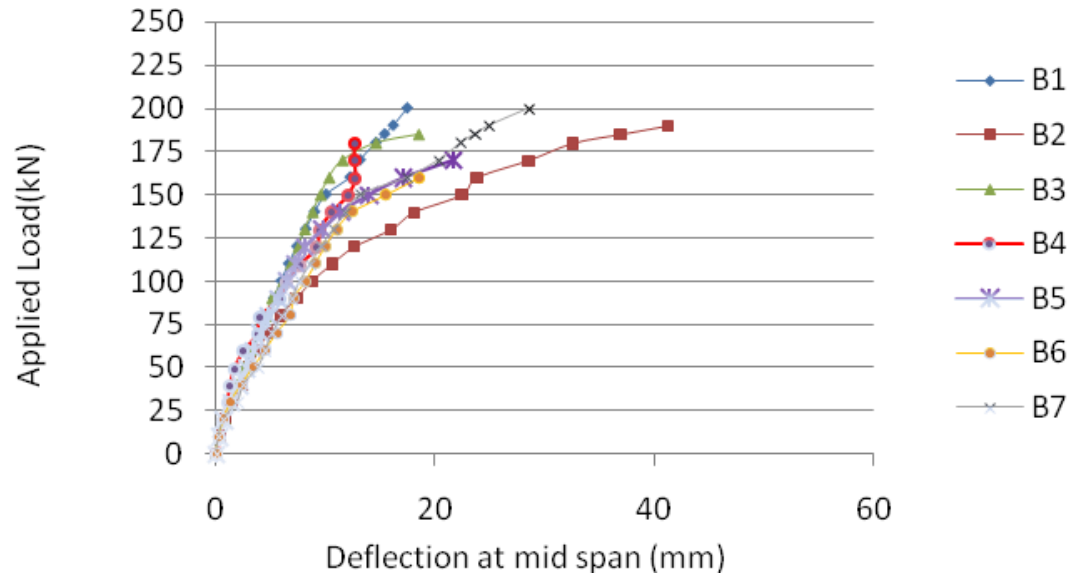

Figure 7: Joists load- deflection behaviors

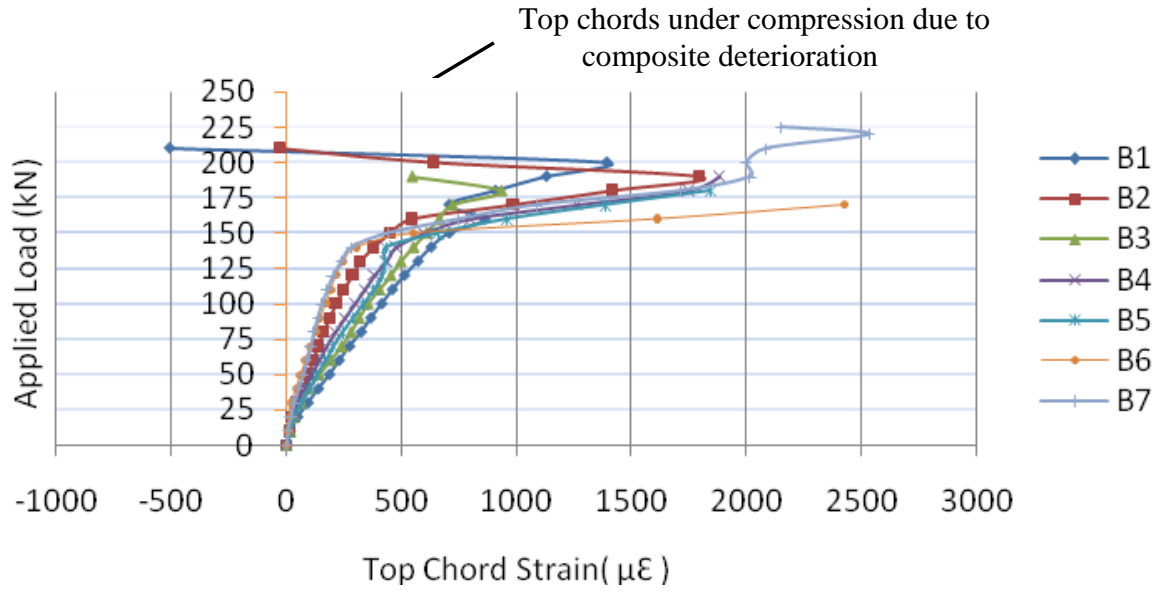

Figure 8: Joists load-top chord strain

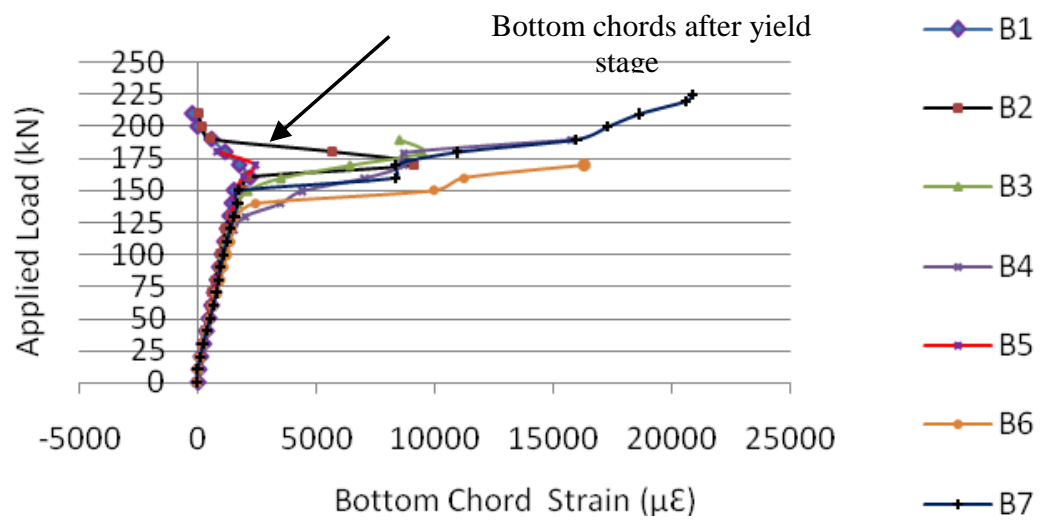

Figure 9: Joists load- bottom chord strain 
j1-g5

j1-G6

j2-G5

j2-G6

j3-G5

j3-G6

j4-G5

j4-G6

j5-G5

j5-G6

.j6-G5

j6-G6

j7-G5

j7-G6

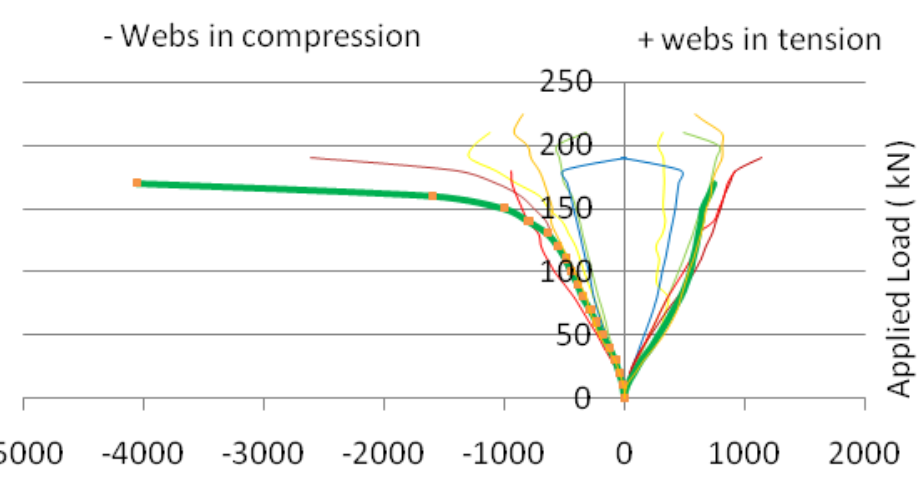

Web Member Strain $(\mu \varepsilon)$

Figure 10: Joists load-web strain

j1-Iv9

j1-lv10

j2 lv 9

j2 Iv 10

j3 Iv 9

j3 Iv10

j4 lv9

j4 Iv10

,j 5 Iv 9

j5 Iv 10

'g6 lv9 60

j6 Iv10

j7 Iv9 Horizontal slips between bottom slab surface and top surface of top

j7 Iv 10 chord $(\mathrm{mm})$

Figure 11: Joists load-slab, top chord horizontal slip

j2

j3

j4

j5

j6

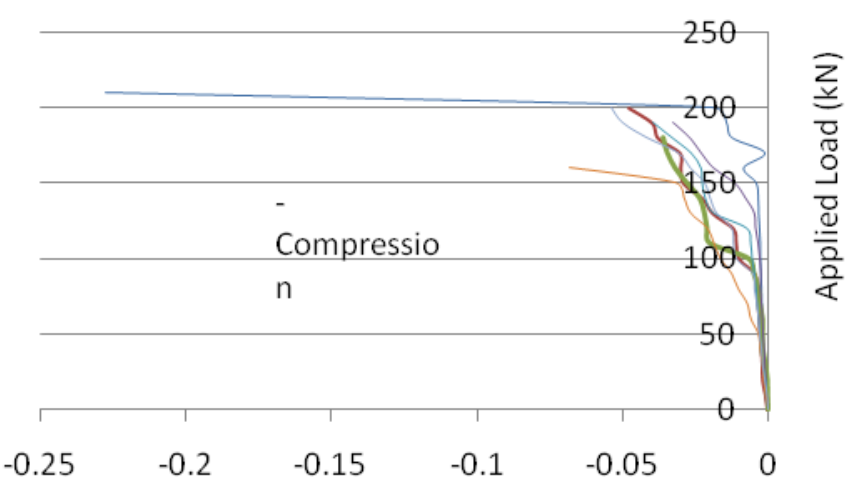

Concrete mid slab top face strain $(\mathrm{mm} / \mathrm{mm})$

Figure 12: Joists load-mid top face slab strain

\section{Conclusions}

1- It was found the long shear stud that embedded in the normal weigh concrete exhibited more ductility $(\mathrm{slip}=0.94 \mathrm{~mm})$, less rigidity $(19$ $\mathrm{kN} / \mathrm{mm}$ ) with higher shear strength (35kNper stud), While the short stud exhibited less ductility $(\mathrm{slip}=0.21 \mathrm{~mm})$, more rigidity $(71.43 \mathrm{kN} / \mathrm{mm})$ with shear strength $(30 \mathrm{kN}$ per stud) which embedded in the same media. On other hand, the shot studs that fixed in light weight concrete slab exhibited ductility (slip $=0.26 \mathrm{~mm})$ and shear strength $(26.5 \mathrm{kN} / \mathrm{stud})$ close to that embedded in 
NJES Vol.21, No.3, 2018

normal weight concrete but with rigidity $(51 \mathrm{kN} / \mathrm{mm})$ less amount than that for stud in normal concrete.

2- Joist of light weight concrete slab resisted lower load carrying capacity of $160 \mathrm{kN}$, while the joist which built with long shear connector resisted $225 \mathrm{kN}$. The remain five joists had the closed value of load capacity ranged from 189$210 \mathrm{kN}$.

3- Comparing with the capacity of each joist with that for the reference joist (joist1) the relative load capacity as follow:

$94 \%$ for Joist 2, $90.5 \%$ for Joist 3, $90.5 \%$ for Joist 4, 90\%for Joist 5, 76.2\% for Joist 6 and Joist 7 has relative capacity $107.143 \%$.

4-From the load- deflection relationships of the seven joists(COWSJs), the joist of the uniform over-connecting stud distribution as CSJ-1, and the joist of the under-connection condition as CSJ-3 have behaved in a high stiffness flexural manner.The Joist of the non-uniform distribution of shear connectors as CSJ-2 has exhibited more ductile performance. The Joist of web-member inclination less than 45 degrees as CSJ-4, and the joist of rounded web members as CSJ-5 have suffered transverse bottom chord displacement, thus, the lateral bracing for the bottom chord is important to avoid such undesired movement. All tested joists have performed quite efficiently as composite flexural members within elastic range behavior.

\section{Hadeed et al., pp.393-404}

\section{References}

[1] Oehlers, D.J. and Bradford, M. A., "Elementary Behavior of Composite Steel and Concrete Structural Members", Butterworth Heinemann, 1999, London, 259 p.9.

[2] Jamal, A.F., "Development of Three- Layers Composite - Concrete Steel Beam Element with Application", Ph.D. Dissertation, University of Technology, June, 2009.

[3] David Samuelson, "Composite Steel Joists", Engineering Journal / Third Quarter, 2002, $111 \mathrm{p}$.

[4] Supplement No 1," Standard specifications for Composite steel Joists and code of standard practice", Steel Joist institute (SJI), Vol. 32, Dec., 2010.

[5] Douglas F. Lauer," Ultimate strength analysis of composite and fully composite open - web steel joists", M.Sc. Thesis, Virginia Polytechnic Institute and state University, October, 1994.

[6] AISC, "Steel Construction Manual", American Institute of Steel Construction, Chicago, Thirteenth Ed., IL, 2005.

[7] BS 5400: Part 5, "Design of composite bridges", British standards institution, London 1979.

[8] ENV 1994-2," Euro Code - 4; " Design of Composite Steel and Concrete Structure, Part 2; General Rules for Bridges ", CEN; 1997.

[9] Mark Lawson and Peter Wickens,"Steel Designers' Manual - Chapter Composite Beams", 6th Edition, 2003.

[10] Colaco, J. P. "A Stub-Girder System for High-Rise Buildings." AISC Engineering Journal, 1972, pp. 89-95

\section{البحث العملي لتصرف العتبات الفولاذية المفتوحة الوترات}

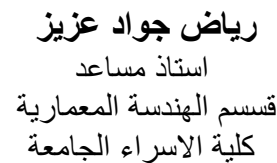

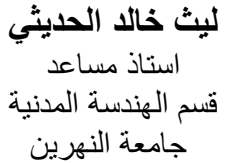

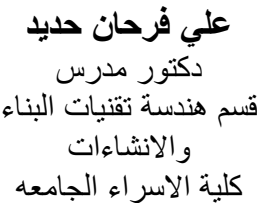

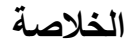

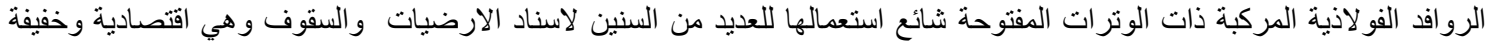

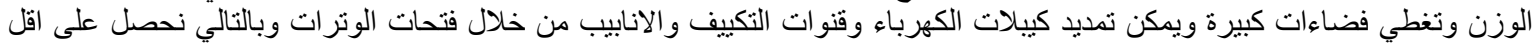

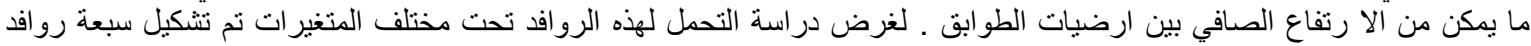

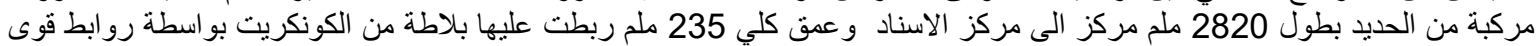

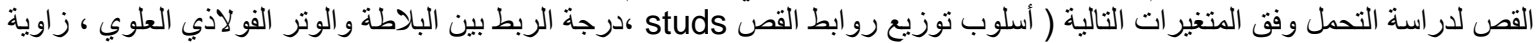

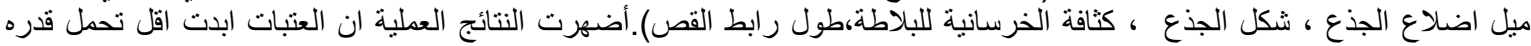

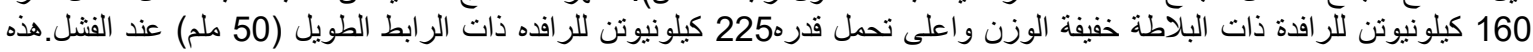

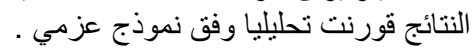

